\title{
The Art Of Persuasion: Pathetic Appeal VIS-À-VIS Ethical And Logical Considerations
}

\author{
Sarah Mwendar Wallace \\ Department of Languages, Linguistics and Literature \\ Pwani University. Kilifi, Kenya \\ Yakobo Mutiti \\ Department of Languages, Linguistics and Literature \\ Pwani University. Kilifi, Kenya \\ Rocha Chimerah \\ Department of Languages, Linguistics and Literature \\ Pwani University. Kilifi, Kenya
}

\begin{abstract}
Short story writing is a literary art whose creativity heavily depends upon the interplay between the writer and his influence upon the reader. There are four modes of discourse employed in creative writing: exposition, description, narration and persuasion. Exposition is concerned with the layout, style and organisation of events and the actors within them. It is the immediate revelation to the readers of the setting and other background information that is necessary for understanding the plot. Description employs the use of language terms in 'graphical' or picturesque representation of something or someone through detailed characterisation of colour, motion, sound, taste, smell and touch. Narration is the telling of a story in fiction, nonfiction, poetry or drama. Persuasion is a form of argumentation where the language employed is intended to convince, principally through appeals to reason or to emotion. This study is focalized on the mode of persuasion with the rhetorical and classical theories as the point of reference. The Greek philosopher Aristotle upheld the view that narration, whose essential purpose is to become persuasive, could only enjoy viability if it possessed the following appeals: ethos, logos, pathos and kairos. This study was a confirmation of Aristotle's contention across first language and second language English readers; this was underscored by an annexed anthology within the study, depicting divergent fictional settings and all emanating from the same writer, to which reading subjects from these variegated contexts were exposed. Thereafter comprehensive questionnaire covering various dimensions of ethos, logos, pathos and kairos was used to elicit the reader responses in regard to their appreciation and understanding of story. The study is useful not only in cementing the classical tradition, but also as an indication that even in modern rhetoric, logos and kairos must be regarded as basic in any communication while ethos and pathos are mainly appellative, although of relative importance.
\end{abstract}

Key Words: narration, exposition, description, persuasion, rhetoric, ethos, logos, pathos, kairos

\section{INTRODUCTORY BACKGROUND}

Creative writing exercised within the genre of short stories has generated enormous debate about the primacy of any of the appeals exhorted by the Greek philosopher Aristotle: the appeal to ethical consideration, reason, sentiment and contextual relevance. Aristotle unequivocally lauded the appeal to reason - logos - as enjoying supremacy over the others. Whereas this study by no means disputes this contention, it nevertheless wants to interrogate 
the levels to which the appeal to sentiment - pathos - can influence the reader of a creative piece of writing; so that the appreciation (sentiment/pathos) established by the reader can be interrogated as emanating either from a feeling of goodwill towards the writer (ethos) or from a logical understanding of the people and events encoded in the text of the story (logos), and the context of the situation in which the story is told (kairos).

\section{THEORETICAL BACKGROUND}

Recording quotidian idiosyncrasies is one of the best ways of being creative; other ways being teaching moral lessons or producing dramatic events. Aesop's fables in ancient Greece, Jean de la Fontaine in France belong to the former morality tier. Honore de Balzac, the French author of La Comedie Humaine (1846) belongs to the latter category with his vast collection of scenes from private and Parisian life. Others who were interested in being creative about the events of ordinary life instead of emphasising dramatic action are Anton Chekov, Russian writer and author of The Party (1888) and The Lady and the Dog (1899). It is interesting to note that two American authors, John Cheever and John Updike, followed in his style. Ann Beattie, Raymond Carver and Joyce Carol Oates have also used the form to record breakdowns in modern life. Edgar Allan Poe, an American author and literary critic, was perhaps the first important writer to analyse short stories as a distinct literary form. In some of his writings, Poe discussed the dramatic effects such as fear and surprise that could be achieved in a short story. His ideas were widely used by the American critic Brander Matthews in the first book written about short story writing: The Philosophy of the Short Story (1901).

What all these writers share in common is the depiction of life in familiar surroundings and African writers have tended to be no different from them. Political themes and themes of social injustice dominated the plots of creative writers like Sembene Ousmane (Les Bouts de Bois de Dieu); Ferdinand Oyono (Le Vieux Negre et la Medaille; Une Vie de Boy); Ngugi wa Thiong'o (The River Between, Weep Not Child); and even surreal themes and themes of sorcery like Wole Soyinka's Enchanted Forest.

Likewise, a number of literary techniques have been developed by short story writers, including the surprise ending and the epiphany. Most surprise endings involve a surprising event or a revealing explanation; this is the specialty of 0 . Henry, an American short story writer who wrote The Furnished Room (1904), The Gift of the Magi (1905), and many other tales. The epiphany is a sudden comment, incident or symbol that can be used at any point in the story to explain the meaning of a complex event. James Joyce, an Irish author of the early 1900s created this technique; he included it in a collection of short stories called The Dubliners (1914).

Therefore in all of the above-mentioned scenarios, narrative persuasion has been manifested either by remaining faithful to daily occurrences or by developing literary techniques; and the common thread running through them all is the effects of pathetic appeal, which has an influence on the reader's appreciation of the creative narrative piece. This study wanted to bring in the perspective of primacy among the appeals of Aristotle; in order to establish which one of them was prevalent. To do so, it relied heavily on rhetorical tools and devices as well as figurative language.

\section{METHODOLOGICAL APPROACH}

The study adopted a qualitative research type of methodology based on words, feelings, emotions, sounds or other non-numerical elements; a methodology that was flexible and investigative. It was also descriptive in nature since its aim was to identify certain facts: those that appertained to ethical, pathetic and logical considerations as the researcher attempted to 
determine which of the three appeals enjoyed any measure of supremacy over the other two. The research design was exploratory whereby final and conclusive answers to the research questions are generally interpreted by the researcher; where the findings were topic-specific within the interrelated narrative, linguistic, and communicational domains of the researcher. The target population were readers of creative writing within the genre of short story writing who were native and non-native speakers of the English language. Participants were drawn from Kilifi Kenya and Jersey UK. One story was distributed and read during the pilot study and another story was read for the main study. The pilot study utilised the instrument of a questionnaire which was further modified appropriately for the main study.

\section{DISCUSSION}

During the pilot study Of Bus Rides and Bottles of Water was the storyline that was distributed to the readers. Where Part 1 constituted elicitation of personal information, Part 2 was more focalized on the three appeals.

Ethos refers to the writer's personality and brings out his or her image as it emerges in the text (Aristotle, 1926). Appearing knowledgeable and experienced with regard to the subject matter being addressed is demonstrated by incorporating testimony; thus good character, which is a measure of one's virtue, can only be demonstrated by calling attention to virtues that are valued by the audience, according to Aristotle. What is valued by the audience therefore has to be shared in common with the narrator: images, attitudes, beliefs, backgrounds, among others. Logos is an appeal to the collective intellect of the audience. According to Aristotle, the audience is better persuaded by a rhetor who provides arguments than by one who does not. The English philosopher Steven Toulmin devoted a substantial amount of time in analysing rhetorical arguments, particularly the elements involved in persuasion. His model of argumentation recognises six levels: the Claim (the conclusion or argument being made); the Grounds (data and facts offered to support the claim); the Warrant (which logically connects the grounds to the claim); the Backing (which supports the warrant); the Qualifiers (which make a statement about the strength of the claim); the Rebuttal (exception to the claim) (Wallace, 2017). Because of the reasoning required within the domain of logical argumentation, a portion of the Toulmin model was included in this research study as a theory that would be complimentary to the rhetorical and classical theories. However, Toulmin's model was limited to only three of the levels of argumentation: the claim, the data and the warrant. Since arguments are inevitably incorporated in the study's storyline, Toulmin's theory is entertained in order to be supportive to Aristotle's logical appeal to reason.

Pathos is none other than emotive appeal. It involves everything which contributes towards producing an emotional state and one which is conducive to accepting the writer's views. The most influential emotions in decision-making are fear, compassion, anger, love, hate, joy, sorrow and hope (Aristotle, 1926). These emotions can be evoked by using both emotive language and rhetorical tools and devices. Within the genre of fiction and specifically creative writing in the form of short stories, which was the core line of interest in this study, pathos plays a pivotal role; the story's impact is diminished as the pathos is diminished, augmented as the pathetic appeal is increased and this is what the study sets out to explore. Lastly, kairos is central in the understanding of the narrative in relation to the author, the audience and the communicative situation in which they are engaged.

\section{SUMMARY}

One story was distributed among a dozen participants, entitled An Almost True Story. All of them were viewed as units that represented a general public of readers of creative writing in the English language. In total there were male and female native and non-native speakers of 
the English language. Annotations within the storyline represented the figurative language as well as the rhetorical tools and devices that were utilised to engender persuasion. Where the pilot study used a tool with ten questions in total, these were modified to 15 questions in the main research study.

Within the main research study Part 1 revealed the following challenges:

- Who qualifies as a native speaker of the English language: individuals with bi-lingual native language competencies had not been foreseen by the researcher; ultimately only those where English had supplanted the other language were allowed to participate.

- Apparently social class, age and gender were not particularly influential factors in the elicitation of emotive appeal.

- Income levels, class distinction and professionalism turned out to be very closely related and therefore produced similar results.

Approximate percentages of personal interrogation in Part 1 of the main study, can be viewed in the following charts.

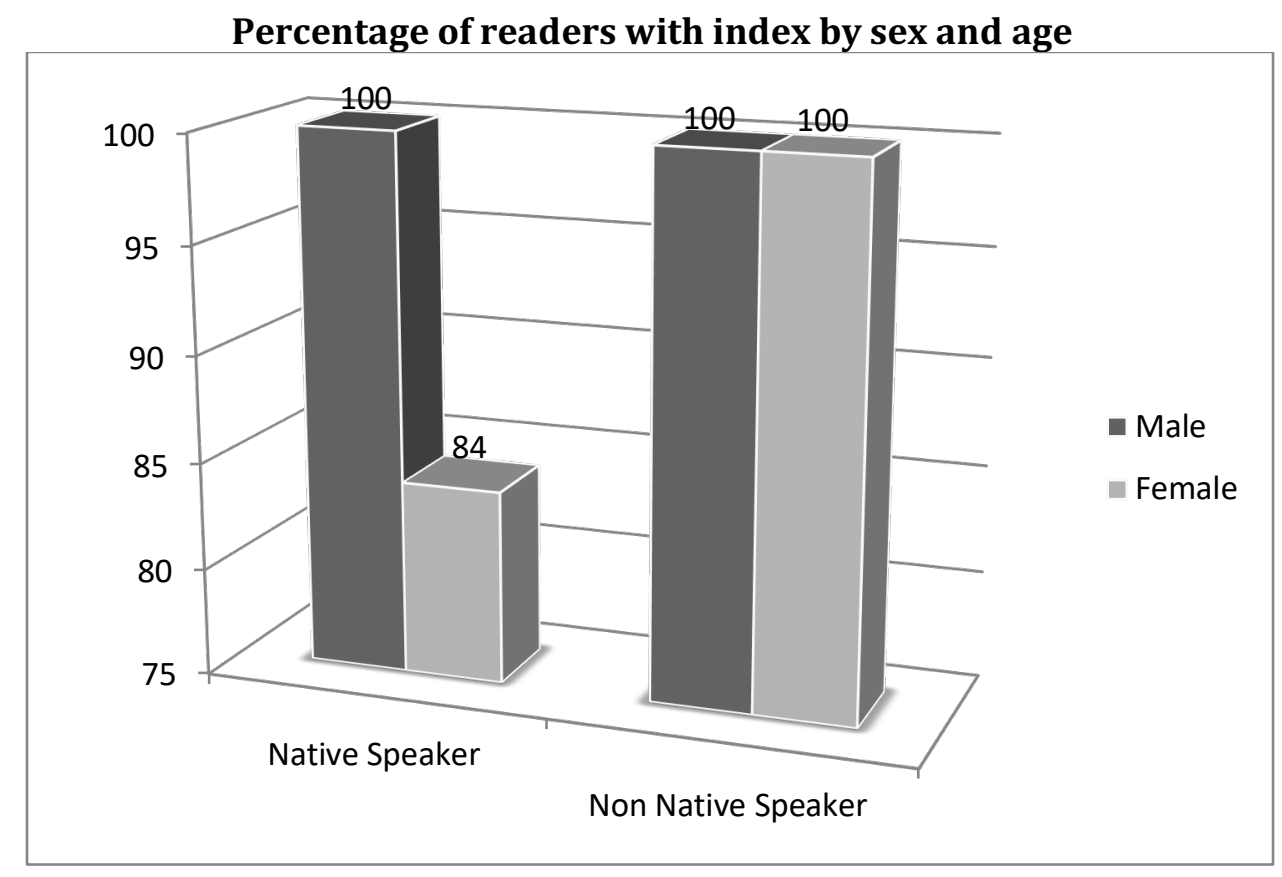

Chart 1 


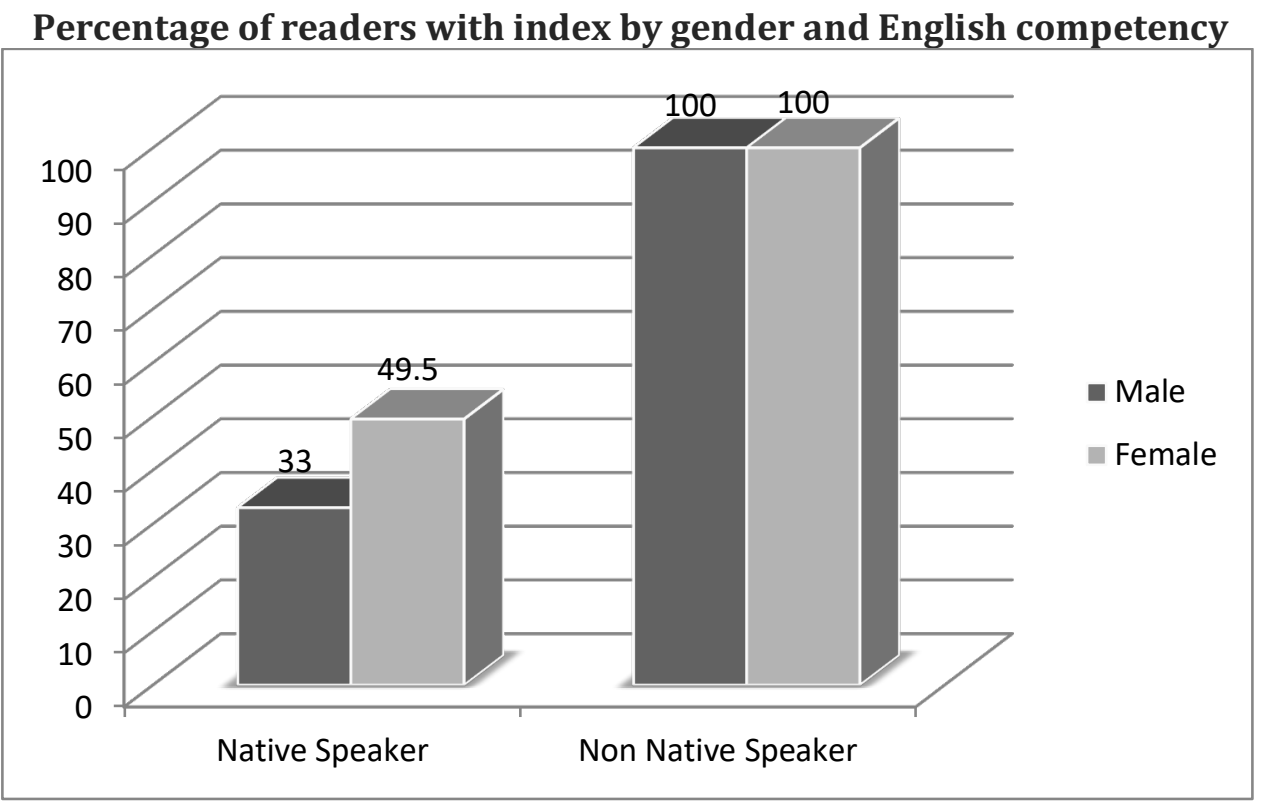

Chart 2

Percentage of readers with index by gender and English competency and formal instruction / profession

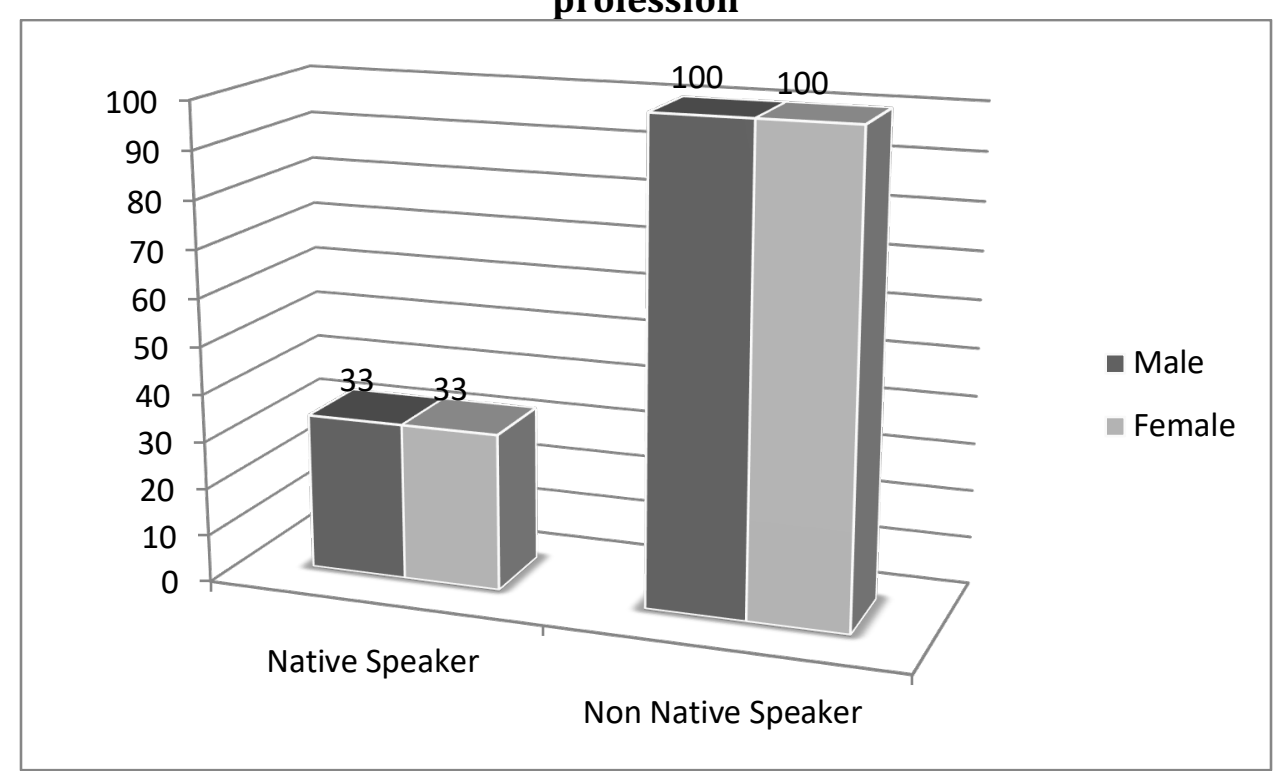

Chart 3 


\section{Percentage of readers with index by gender and English competency and social class distinction}

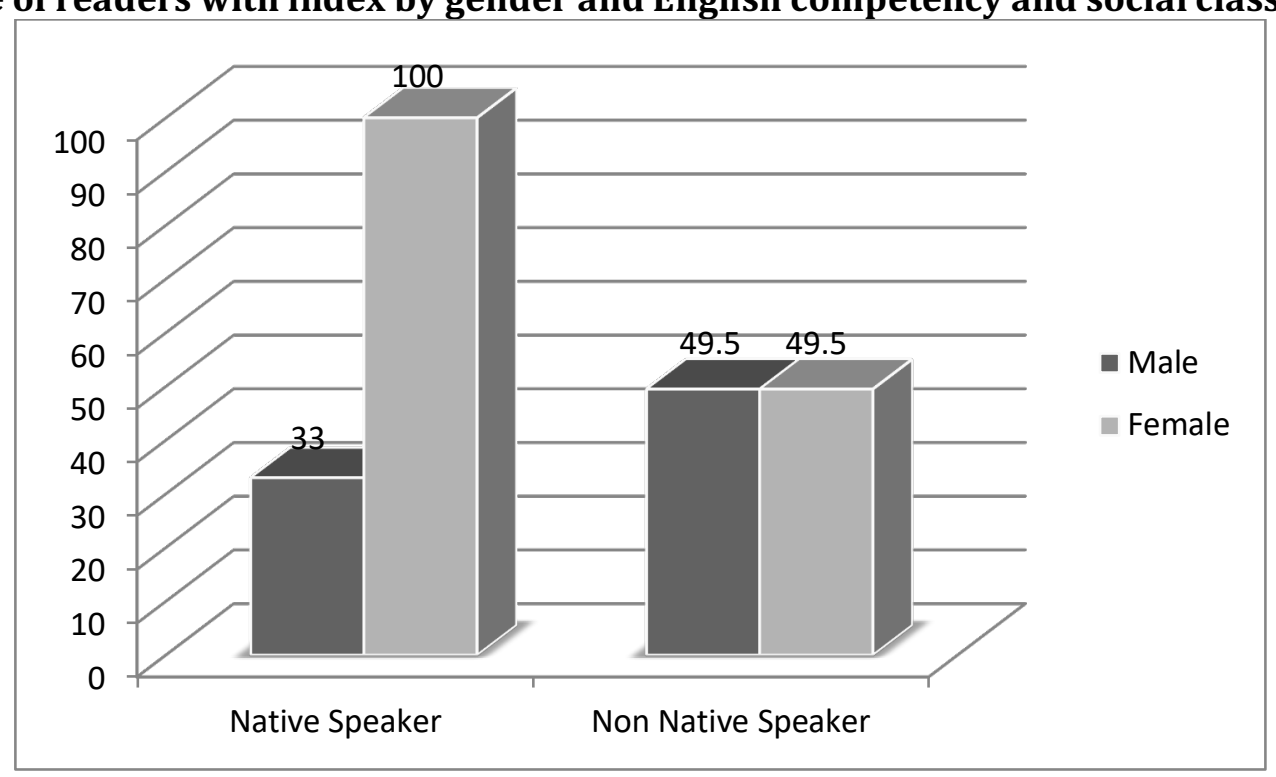

Chart 4

In Part 2 the various strata produced more distinct results where the general inferences drawn by the researcher were more clear-cut:

- Generally-speaking females are more accepting of an outcome than males

- Native speakers of English are capable of remaining detached where non-native speakers are deeply influenced by the protagonists and their actions.

- Ethical appeal drew a wide and varied spectrum of epithets which was highly intended by the researcher right from the onset however, the fact that some proposed answers in the multiple choice options would turn out to be complete opposites of each other was not entirely foreseen; for instance ominous language is totally different from language that is indistinct.

- Maintaining interest in a storyline is paramount to achieving a constant level of persuasion.

- Curiosity is similar to interest and both these sentiments attest to a respectful level of reasoning rather more than to emotive appeal.

- Logical appeal appears to have been more enticing to the male native speakers of English, at a slightly higher percentage than their female counterparts.

- Pathetic appeal was dominant as an overriding perception of the storyline but only among all of the non-native speakers of the English language.

Challenges confronted by the readership within the main research study were accommodated in a separate cover as additional personal commentary that the participants were encouraged to provide. None of the non-native speakers of English offered additional observations. But some of the native speakers were happy to profit from this liberty where:

- Native speaker competency had to be thrashed out during the recruitment of participants

- Answer choices on offer were found to be insubstantial

- Chagrin towards the question about title appropriateness drew opposing responses: where one was in consternation about the question being asked at all, another was overjoyed at the parallelism of the logical sequence of events with an incident in real life that had been embellished by literary creativity

The story that was read in the main study was titled An Almost True Story. The results of the research study therefore were that: 
- Non-native (or second-language speakers) of English are prone to heavy emotive influence when rhetorical tools and devices are used to persuade them.

- Native speakers of English, irrespective of age and gender are simply not affected in the same way as non-native speakers of English, no matter what rhetorical tools and devices are utilized.

- Where pathetic appeal is vital in persuading the readership and even often surpasses ethical appeal, it nevertheless takes second place to logical appeal when the readership professes to appreciate the latter as the driving force behind maintenance of curiosity, interest and any surprise factor within the peroration of the storyline.

- In practical rhetorical exercise, the appeals of pathos, ethos and logos are complimentary to each other; if primacy has to be established, then logos appears to enjoy dominance over the other two narrative appeals because without it the other appeals would be far harder to discern or to have any effect at all upon the readership; therefore what can be construed as common sense on the face of it, has now been proven beyond the shadow of a doubt by the researcher's anthology within this main study (annexed section) and its varied and diversified settings and circumstances.

- No matter what the socio-cultural disposition within the storyline, a logical sequence of events and the actors in those events are what determines the levels of ethical consideration and sentimental value.

\section{An Almost True Story}

\section{APPENDIX: THE STORY}

As he stood in front of that simple wooden door, a warm feeling of anger started rising up from his chest and engulfing the base of his neck. Then it began slowly to choke then strangle him. Feelings of resentment and low self-esteem swirled around in his head. Why was every man looking lustfully at his fiancée? ${ }^{1}$ She was meant as a future wife for him, not for them. Was he imagining or had she returned a coy look at his macho bearded cousin-brother Ahmed? ${ }^{2}$ No, something had to be done. Something had to be done ${ }^{3}$ about the prevailing state of affairs. He had to take steps and make sure that no man ever looked upon her in desire again. He would ensure that she herself never saw another man in her life after setting her eyes on him today ${ }^{4} .$.

So he knocked on the door. Her mother opened it, and it was all he could do to contain the pent-up rage that was giving him indigestion. ${ }^{5}$ After the usual salutations he made for the bedroom door just as she herself opened it. His hand darted into his pocket and he pulled out the little jar within it. As soon as she raised her face to look at him and greet her husband-to-be with respect, and some of the love she felt towards him lately, he opened the jar and tossed its contents squarely onto her face. Acid. ${ }^{6}$ She screamed! She screamed and screamed and screamed and screamed. ${ }^{7}$ She screamed until she was hoarse. Never in her whole life had she felt such pain. Her screams shattered the silence in the house; they pierced the hearts of every living person within hearing; her pain was felt by each human soul in that vicinity. ${ }^{8}$ Then she collapsed in a small heap on the floor - mercifully it seemed.

He on the other hand turned and fled. He ran and ran....away from that scene, that ${ }^{9}$ house where he had carried out his cowardly, dastardly deed ${ }^{10}$; he ran away from the imprinted memory of a pain and suffering he simply could not fathom or understand properly. Justice had been served thought he. ${ }^{11}$ She would survive he consoled himself. Acid does not kill. But she would survive as his wife, for him alone, not for other men to ogle at but, for him, just him, for him to admire, his own wife, his personal possession, his alone - his!!

$\underline{\text { And survive she did }}^{13}$. Her mother and other women in the house picked her up and rushed her to the nearest dispensary. This case would be reported to the Chief Kadhi. Her fiancé would not 
go unpunished. Vengeance would be retributed ${ }^{14}$. Not long after that incident they were told how. The general consensus among the village elders and the Chief Kadhi was that Islamic Law in this case advised 'an eye for an eye' ${ }^{15}$ since the two were only betrothed and not yet married to one another. The perpetrator was found guilty of grievously harming someone who had done no active harm to him; his assault had been based on supposition and imagined passive aggression according to them; none of his allegations could be proved and many were the witnesses who saw or heard what had transpired that day. So they surmised that he deserved to suffer the same pain as she - not by her own hand but by the hand of the village executioner, whose normal duties included lashing, stoning, mutilation and beheading. The only way the convict could escape the price he had now to pay was if the victim chose to forgive him, according to Islamic Law. As for the victim, she acquiesced that she could in fact find it in her heart to forgive him but only if he asked for her forgiveness.

No. $\underline{\text { No }}^{16}$. No, this was not going to happen. Did women rule the world now he wondered? He, a full-grown man ripe for marriage, was he now going to feebly apologize to a woman who had, perhaps inadvertently, hurt his deepest feelings, one who had aroused his worst and most powerful feelings of profound jealousy? Noooooooo. He was way too proud to apologize to her. ${ }^{17}$ This religion, whilst putting him on a masculine pedestal was now striping him of that very virtue (just being born a man was a virtue to him) by offering him an effeminate alternative that was giving him nausea, nausea ${ }^{18}$. He would never apologize to a member of the weaker sex about something that he as a man had decided - never! ${ }^{19}$

Even the prospect of being blind for the rest of his life - like his now blind fiancée - did not make him think otherwise. No he was not sorry, she deserved it! He would not bend, he could not bend his will. He would remain steadfast to his convictions.

Then the day for sentencing dawned on that little Muslim village. The poor newly-blind victim was escorted by her female counterparts to the executioner's house - a house in a compound that was rightly feared by all who ventured there whether guilty or not; a sad, simplistic, squalid little house ${ }^{20}$ surrounded by yellowing grass, that was enclosed by a wooden fence the other side of which lay the village cemetery. The belligerent perpetrator was also escorted there - by armed guards and a large crowd of boys and men who were all drawn to this place by reason of entertainment, curiosity also having got the better of them.

The procedure was that the executioner would first secure him on a bed using strong ropes. Then he would ask the convict three times whether or not he was remorseful about his actions and wanted forgiveness. Should he ask her for forgiveness and the victim choose not to grant it, he would suffer the consequences, just as he would should he maintain his belligerence. ${ }^{21}$

The women were herded ${ }^{22}$ out into the main hall. The only occupants in the execution room were the Chief Kadhi and a few octogenarian elders, the cocky, young perpetrator and the apathetic blind victim of his actions. ${ }^{23}$ She sat alone and apart from the men, now relying on her sense of hearing more than ever before since she could no longer see.

“ Do you request for forgiveness for your actions ${ }^{24}$ ?" asked the burly executioner with the bulbous nose and watery eyes. " No I do not!" said the young man. The executioner's big thick fingers of one hand stretched out to grab a big jar full of acid." Do you request for forgiveness for your actions?" he asked again, his big tongue darting about to lick the thick lips ${ }^{25}$ in an attempt to keep them moist. " NO!!" - shouted the young man although this time round his voice inflection betrayed a wavering in the whining, as he contemplated his impending doom. The thick fingers of the other hand belonging to the executioner now joined the first set of 
fingers in removing the lid from the big jar of acid. "Do you request for forgiveness for your actions?" asked the monolith with finality, at which the young man audibly whispered "No" and broke into tears; for now the fear was all too real, the fear of becoming blind and unable to see.

"Wait!" said the young blind woman "I want to say something if I may". The Chief Kadhi lifted his soft, supple, plump, gold ring-adorned hand as a gesture to stop the executioner, then turned to her and allowed her to speak. "I want to ask you my husband-to-be, why do you cry?"

Even the crowds milling outside, heard her soft, gentle little voice wafting through the loudspeaker atop the roof of the executioner's dour house. Amidst plaintive sobs the young man spluttered out "It's not the actual sentence of blindness by acid, it's not even the lifetime of not being able to see that awaits me..... just can't forget the scream of pain that pierced my ears, $\underline{\text { my }}$ whole being, $\underline{\mathrm{my}}^{26}$ very soul. I fear that pain that I caused you - a pain that haunts me day and night ever since you expressed it so fearfully; a sound so shrill, a pain so excruciatingly shrieked out Oh God..." - "Stop 27 !" she shouted "I have forgiven him!"

Away in another foreign country in Europe, the television correspondent carrying out an interview with a woman clad in Muslim attire with nothing revealed save the eyes covered in black sunglasses, wondered aloud in her interrogation of the victim; why she forgave her fiancé after what he had done to her and with no show of remorse. "The fact that he realized the extent of the pain he had caused me, the physical and psychological pain that he had inflicted upon me....that was enough for me to forgive him" she explained. The realization then, more than mere words of apology, convinced the suffering woman that her attacker was himself in a far worse pain than acid could inflict: the very real pain of apprehensive anticipation...

The Chief Kadhi was visibly relieved, as were his peers. The executioner felt robbed ....of a pleasure he might have enjoyed - the pleasure of retribution which normally leaves a bittersweet taste in the mouth (as opposed to plain cruelty which leaves his mouth completely dry). The crowd outside were hooting and booing 28 simultaneously. A heavy curtain of guilt and humility and sheer and utter gratefulness ${ }^{29}$ engulfed the young culprit, with the reality that he had been spared a fate that was perhaps worse than death itself. And she ...was finally at peace with her fate ... in that village $\underline{\mathrm{in}}^{30}$ the desert, the back of beyond ... $\underline{\text { finally at peace }}^{31}$.

NB. The annotations are indicative of the figurative language and particular rhetorical tools and devices in use.

\section{REFERENCES AND BIBLIOGRAPHY}

Weller S., Romney A 1988. Systematic Data Collection (Qualitative Research Methods Series 10).Thousand Oaks, California: SAGE Publications, ISBN 0-8039-3074-7

Fasold R, 1990. The Sociolinguistics of Language. Basil Blackwell Ltd. USA

Muller GH, Wiener HS, 2006. The Short Prose Reader Examination Copy Eleventh Edition.The McGraw-Hill Companies Inc. New York USA

Yule G., 1995. The Study of Language Cambridge University Press, UK

Bloomfield L, 1933.Language. New York: Henry Holt and Company.

Brown G and Yule G. 1983. Discourse Analysis. Cambridge University Press.

Chambers JK and Trudgill, P. 1980. Dialectology. Cambridge University Press.

Chappell VA and Gillam AM, 2002. Instructor's Manual, Reading Rhetorically. Pearson Education USA.

Corbett EPJ, “Introduction.” 1985. Rhetorical Analyses of Literary Works, ed. By E. Corbett.Oxford Univ. Press. 
Downes W.,1984. Language and Society. Fontana Paperbacks.

Dumont P., Maurer, B., 1995. Sociolinguistique du Français en Africque Francophone, Edicef / Aupelf.

Fishman J., 1971, Sociolinguistique, Nathan, France.

Jacobson R., 1963. Essais de Linguistique Générale, Éd. du Seuil.

Labov W. 1972.Sociolinguistic Patterns. University of Pennsylvania Press. USA

Roberts E.V., 2003. Writing About Literature.10 ${ }^{\text {th }}$ Ed. Pearson Education Inc. New Jersey, USA.

Rubinelli S, 2009. ArsTopica: The Classical Technique of Constructing Arguments from Aristotle to Cicero. Springer.

Saville-Troike M, 1977. Linguistics and Anthropology.Georgetown University Round Table on Languages and Linguistics. Washington, DC: Georgetown University Press.

Steinberg S., 2006. Persuasive Communication Skills. Juta \& Co.

Toulmin S 2003. The Uses of Argument, rev.ed.Cambridge Univ. Press.

Trudgil P. 1974. Sociolinguistics: An Introduction. Penguin Books.

VanEemeren FH and Grootendorst R., 2004. A Systematic Theory of Argumentation. Cambridge Univ. Press.

VanEemeren et al., 2002. Argumentation: Analysis, Evaluation, Presentation. Lawrence Erlbaum.

Wallace SM, 2017. The Art of Persuasion: Using Rhetorical Means to Discuss Speech, Poetry and Prose. Printed by 4P Publishers Mombasa. Published by EI Ltd. Nairobi, Kenya.

Winterowd WR, 1981. The Contemporary Writer. Harcourt. 